\title{
Structural Properties of the RNA Synthesized by Glutamate Dehydrogenase for the Degradation of Total RNA
}

\author{
Godson 0. Osuji, Paul M. Johnson \\ Plant Systems, College of Agriculture and Human Sciences, Prairie View A \& M University, Prairie View, Texas, USA \\ Email: goosuji@pvamu.edu,professorosuji@yahoo.com
}

How to cite this paper: Osuji, G.O. and Johnson, P.M. (2018) Structural Properties of the RNA Synthesized by Glutamate Dehydrogenase for the Degradation of Total RNA. Advances in Enzyme Research, 6, 29-52.

https://doi.org/10.4236/aer.2018.63004

Received: July 5, 2018

Accepted: September 11, 2018

Published: September 14, 2018

Copyright $\odot 2018$ by authors and Scientific Research Publishing Inc. This work is licensed under the Creative Commons Attribution International License (CC BY 4.0).

http://creativecommons.org/licenses/by/4.0/

\begin{abstract}
Glutamate dehydrogenase (GDH)-synthesized RNA, a nongenetic code-based RNA is suitable for unraveling the structural constraints imposed on the regulation (transcription, translation, siRNA etc.) of metabolism by genetic code. GDH-synthesized RNAs have been induced in whole plants to knock out target mRNA populations thereby producing plant phenotypes that are allergen-free; enriched in fatty acids, essential amino acids, shikimic acid, resveratrol etc. Methods applied hereunder for investigating the structural properties of GDH-synthesized RNA included purification of GDH isoenzymes, synthesis of RNA by the isoenzymes, reverse transcription of the RNA to cDNA, sequencing of the cDNA, computation of the $\mathrm{G}+\mathrm{C}$-contents, profiling the stability through PCR amplification compared with genetic code-based DNA; and biochemical characterization of the RNAs synthesized by individual hexameric isoenzymes of GDH. Single product bands resulted from the PCR amplification of the cDNAs of GDH-synthesized RNA, whereas several bands resulted from the amplification of genetic code-based DNA. The cDNAs have wide $\mathrm{G}+\mathrm{C}$-contents (35\% to $59 \%$ ), whereas genetic code-based DNA has narrower $\mathrm{G}+\mathrm{C}$-contents ( $50 \%$ to $60 \%)$. The $\mathrm{GDH} \beta 6$ homo-hexameric isoenzyme synthesized the A+U-rich RNAs, whereas the a6, and $a 6$ homo-hexameric isoenzymes synthesized the G+C-rich RNAs. Therefore, the RNA synthesized by GDH is different from genetic code-based RNAs. In vitro chemical reactions revealed that GDH-synthesized RNA degraded total RNA to lower molecular weight products. Therefore, GDH-synthesized RNA is RNA enzyme. Dismantling of the structural constraints imposed on RNA by genetic code liberated RNA to become an enzyme with specificity to degrade unwanted transcripts. The RNA enzyme activity of GDH-synthesized RNA is ubiquitous in cells; it is readily induced by treatment of plants with mineral nutrients etc. and may simplify experimental approaches in plant
\end{abstract}


enzymology and molecular biology research projects.

\section{Keywords}

RNA Enzyme Synthesis, Nongenetic Code-Based RNA, Cloning Vector DNA, Touch-Down PCR, Frame Shift Sequence Homology

\section{Introduction}

Glutamate dehydrogenase (GDH EC 1.4.1.2) is a multi-subunit enzyme that polymerizes ribo-nucleoside triphosphates to produce RNA independent of any template [1] but dependent on the enzyme's binomial hexameric subunit composition, a property that is controlled by metabolic environments [2] [3]. Therefore, RNA synthesized by GDH is not genetic. Plant GDH synthesizes large quantities of RNA [4]. The same sequence and population of RNA are synthesized irrespective of the reducing or oxidizing reaction conditions. GDH is functional in all organisms. The metabolic nature of GDH-synthesized RNA provides the opportunity to study the chemical contrasts between genetic code-based and nongenetic code-based RNAs for the differentiation of their biological functions. The GDH-synthesized RNA shares sequence homologies with many mRNAs [1]. They regulate total RNA abundance [5]. GDH-synthesize RNAs have been reverse-transcribed to cDNA and sequenced, leading to large scale preparation of the silencing oligonucleotides, which are routinely applied as tools for monitoring mRNA concentrations, and metabolic networks that coordinate the biochemical pathways [4]. GDH isoenzymes have been induced in whole plants to synthesize selected sets of RNA that knocked out target mRNA populations thereby producing plant metabolic variants that are specialized in the accumulation of many metabolites of dietary importance. Specifically, allergen-free low linoleic acid peanuts [6], fatty acid-enriched peanuts [3], essential amino acid-enriched peanuts [7], ultra-high nutraceutical resveratrol contents of peanut seeds [8], shikimic acid-enriched Phyla dulcis plants [9]; and doubling of biomass yield [4] are some of the biotechnological milestones achieved by unleashing the mRNA degradation activity of GDH-synthesized RNA. The mechanisms of RNA enzyme, and transcript silencing are known [10] [11] [12], but the chemistry by which GDH-synthesized RNA (nongenetic code-based RNA) degrades total RNA (genetic code-based RNA) has not been discussed [5]. RNA-RNA interactions have been studied in detail [13] [14] [15], but the homologous alignment interactions in solutions, between nongenetic code RNA and genetic code-based RNA have not been studied. This paper opens a conversation on the in vitro reactions between GDH-synthesized RNA and total RNA moieties.

Following the biotechnological applications of GDH-synthesized RNA as enzyme, there is need to characterize their chemical properties as compared with genetic code-based RNA. There are many contrasts in the chemistry of coding 
RNA and non-coding RNA [16] [17] [18] [19] [20]. Both coding and noncoding RNAs are however genetic. It is important that genetic code-based and nongenetic code-based RNAs are compared so as to begin to unravel the constraint and freedom imposed on metabolic regulation (siRNA silencing, transcription, replication, translation, genome structure etc.) by genetic code. Methods for investigating RNA generalized molecular properties revolve around the computation for $\mathrm{G}+\mathrm{C}$ - and $\mathrm{A}+\mathrm{T}$-compositions and nearest neighbor base stacking interactions after RNA has been converted to cDNA [21] including algorithmic analyses for probable intramolecular binding sites [13]. Although $\mathrm{G}+\mathrm{C}$ contents have been applied repeatedly in the description of nucleic acid structure [16] [17] [18] [20], the biochemical basis of the differential distribution of $\mathrm{G}+\mathrm{C}$ in genomes has not been discussed. Other structural properties of nucleic acids are controlled by hydrogen bonding-related stabilization, melting and annealing temperatures, paramagnetic and electrostatic instability, interactions with protein enzymes and ligands [22] [23] [24]. Most of the properties including the $\mathrm{G}+\mathrm{C}$ contents could be deduced by subjecting the cDNA to polymerase chain reaction (PCR) amplification, one of the experimental approaches presented hereunder. The structural differences between GDH-synthesized RNA and genetic code-based RNA illuminate the catalytic properties of GDH-synthesized RNA.

\section{Materials and Methods}

\subsection{Treatment of Experimental Organism}

Peanut (Arachis hypogeae Floor Runner cv.) seeds were sterilized in 5\% alcohol solution for $10 \mathrm{~min}$, rinsed with deionized water, and planted on moistened filter paper in five replicate petri dishes. The compositions of the mineral nutrients were: $\underline{\mathrm{N}+\mathrm{N}+\mathrm{N}+\mathrm{K}+\mathbf{S}+\mathbf{S}}$ ( $1 \mathrm{~L}$ of $75 \mathrm{mM} \mathrm{NH}_{4} \mathrm{Cl}, 4 \mathrm{mM} \mathrm{KCl}, 100 \mathrm{mM} \mathrm{Na}_{2} \mathrm{SO}_{4}$ ); $\underline{\mathrm{N}+\mathrm{P}+\mathrm{K}+\mathrm{K}+\mathrm{K}}\left(1 \mathrm{~L}\right.$ of $\left.25 \mathrm{mM} \mathrm{NH}_{4} \mathrm{Cl}, 20 \mathrm{mM} \mathrm{Na} \mathrm{PO}_{4}, 12 \mathrm{mM} \mathrm{KCl}\right)$; $\underline{\mathrm{N}+\mathrm{P}+\mathrm{S}+\mathrm{S}+\mathrm{S}+\mathbf{S}}$ (1 L of $25 \mathrm{mM} \mathrm{NH}_{4} \mathrm{Cl}, 20 \mathrm{mM} \mathrm{Na}_{3} \mathrm{PO}_{4}, 200 \mathrm{mM} \mathrm{Na}_{2} \mathrm{SO}_{4}$ ); $\underline{\mathrm{N}+\mathrm{P}+\mathrm{P}+\mathrm{P}}\left(1 \mathrm{~L}\right.$ of $\left.25 \mathrm{mM} \mathrm{NH}_{4} \mathrm{Cl}, 60 \mathrm{mM} \mathrm{Na}_{3} \mathrm{PO}_{4}\right)$. The control was moistened with distilled water. About 8 - 10 seeds were planted per petri dish and allowed to germinate in the greenhouse temperature of $24^{\circ} \mathrm{C}-28^{\circ} \mathrm{C}$, and relative humidity of $70 \%-80 \%$ under Texas month of May temperature and sunlight conditions. The greenhouse was shaded $50 \%$ with a shade cloth. Filter papers were changed and re-wetted with fresh mineral solutions daily. The applied mineral salt compositions were based on stoichiometric combinations to mimick the binomial subunit polypeptide compositions of GDH isoenzymes [25] [26] and to interact with seeds' target molecules in molar ratios. After emergence of full plumule, germination was stopped; and the seedlings were stored in $-30^{\circ} \mathrm{C}$ freezer.

\subsection{Total RNA}

Total RNA was extracted from peanut seedlings using the acidic phenol/chloroform 
(pH 4.5) method [27].

\subsection{Purification of GDH Isoenzymes}

GDH was purified from the $\mathbf{N}+\mathrm{N}+\mathrm{N}+\mathrm{K}+\mathrm{S}+\mathrm{S}$-treated peanut seedlings $(20 \mathrm{~g})$ by homogenization at $4^{\circ} \mathrm{C}$ with $100 \mathrm{~mL}$ of buffer [28] containing 5 units per $\mathrm{mL}$ of each of RNase A, and DNase 1. The homogenate was centrifuged $(5000 \times \mathrm{g}, 15$ $\min , 4^{\circ} \mathrm{C}$ ), and the supernatant was frozen at $-80^{\circ} \mathrm{C}$, thawed at room temperature in order to fracture the mitochondria and to assure that DNA and total RNA have been degraded. After re-centrifugation $\left(9000 \times \mathrm{g}, 4^{\circ} \mathrm{C}, 30 \mathrm{~min}\right)$, the supernatant was subjected to fractional ammonium sulfate precipitation, preparative-scale isoelectric focusing (IEF; Rotofor, Bio-Rad, Hercules, USA) followed by dialysis of the fractions as described before [4]. Rotofor fractions $(0.2$ $\mathrm{mL}$ ) were purified by native $7.5 \%$ polyacrylamide gel electrophoresis (PAGE) $\left(100 \mathrm{~V}, 16 \mathrm{~h}, 4^{\circ} \mathrm{C}\right)$ to remove other proteins, and nucleic acid contaminations. $\mathrm{GDH}$ isoenzymes were eluted ( $30 \mathrm{~min}, 100 \mathrm{~V}$ ) from the electrophoresed gel with $0.05 \mathrm{M}$ solution of Tris base, at subzero temperature in the elution chamber, of mini-whole gel eluter (Bio-Rad) as described before [29]. The eluted GDH charge isomer fractions were collected separately per eluter channel, and stored at $-30^{\circ} \mathrm{C}$.

\subsection{RNA Synthesis by GDH}

RNA was synthesized in the amination direction in cocktails containing solution of $0.87 \mathrm{mM} \mathrm{NH}_{4} \mathrm{Cl}, 3.5 \mathrm{mM} \mathrm{CaCl}_{2}, 10.0 \mathrm{mM} \alpha$-ketoglutarate ( $\alpha$-KG), 0.23 $\mathrm{mM}$ NADH, $0.6 \mathrm{mM}$ each riboNTP, $5 \mathrm{U}$ of RNase inhibitor, $5 \mathrm{U}$ of DNase 1 , and $5.0 \mu \mathrm{g}$ actinomycin $\mathrm{D}$. The reaction was started by adding $0.2 \mathrm{~mL}$ of cryo-electrophoretically purified GDH charge isomers containing about $500 \mu \mathrm{g}$ protein per $\mathrm{mL}$ as described before [29]. The final volume of the reaction was brought to $0.4 \mathrm{~mL}$ and $\mathrm{pH} 8$ with $0.1 \mathrm{M}$ Tris- $\mathrm{HCl}$ solution. Reactions were incubated at $16^{\circ} \mathrm{C}$ overnight $(16 \mathrm{~h}$ ) and stopped by phenol-chloroform ( $\mathrm{pH} 4.5)$ extraction of the GDH. The RNA was precipitated with ethanol. RNA synthesis was carried out three times to verify the reproducibility of the results.

\subsection{Restriction Fragment Differential Display PCR}

cDNAs were synthesized with $2 \mu \mathrm{g}$ of each product RNA synthesized by the GDH charge isomers purified from the $\mathrm{N}+\mathrm{N}+\mathrm{N}+\mathrm{K}+\mathrm{S}+\mathrm{S}$-treated seedlings, using random hexamer primers. The product cDNA $(5 \mu \mathrm{g})$ was digested with Taq 1 restriction enzyme ( 5 Units) for $2 \mathrm{~h}$ at $65^{\circ} \mathrm{C}$. In order to compare with the chemistry of genetic code-based DNA, pCR4-TOPO vector DNA (5 $\mu \mathrm{g})$ was similarly digested in another micro tube with Taq 1 restriction enzyme (5 Units). Adaptors, ${ }^{32} \mathrm{P}$-labeled extension primers, and the selective display PROBE combination (Display Systems Biotech, Vista, CA USA) were ligated to the ends of the restriction fragments. The nucleotide sequences of the adapters, extension 
primers, and display PROBEs are among the proprietary information of their manufacturer, Display Systems Biotech, Vista, CA USA.

The template DNA $(0.5 \mu \mathrm{g})$ was amplified according to the 'touch-down' restriction fragment double display (RF-DD) PCR methods of Display Systems Biotech, Vista, CA, USA. Initial denaturation was $96^{\circ} \mathrm{C}$ for $1 \mathrm{~min}$. For the first 10 cycles: denaturation was at $96^{\circ} \mathrm{C}$ for $30 \mathrm{sec}$., annealing was at $60^{\circ} \mathrm{C}$ for $30 \mathrm{sec}$, for the first cycle, then reduced the annealing temperature $0.5^{\circ} \mathrm{C}$ each cycle until an annealing temperature of $55^{\circ} \mathrm{C}$ was reached after 10 cycles; extension was at $72^{\circ} \mathrm{C}$ for $1 \mathrm{~min}$. PCR was continued another 25 cycles: denaturation $\left(96^{\circ} \mathrm{C}, 30\right.$ sec), annealing $\left(55^{\circ} \mathrm{C}, 30 \mathrm{sec}\right)$, extension $\left(72^{\circ} \mathrm{C}, 1 \mathrm{~min}\right)$; final elongation $\left(72^{\circ} \mathrm{C}\right.$, $5 \mathrm{~min})$. All the 64 display PROBEs in the Display Systems Biotech kit were used in the differential display PCR. The differential bands/products were visualized by autoradiography following polyacrylamide sequencing gel electrophoresis. Selected cDNA, and vector DNA fragments were sub-cloned into pCR4-TOPO vector and transformed into TOP10 One Shot Chemically Competent (non-pathogenic) Escherichia coli (Invitrogen, Carlsbad, CA), followed by overnight growth on kanamycin selective plates. Up to 15 positive transformant colonies were picked per plate and cultured overnight in LB medium containing $50 \mu \mathrm{g} / \mathrm{mL}$ of kanamycin. Plasmids were purified with a plasmid kit (Novagen, Madison, WI), and the insert cDNA or vector DNA fragment of selected recombinant plasmids were sequenced with T7, and T3 primers by MWG Biotech Inc., High Point, North Carolina, USA. The sequenced plasmids were amplified by 'touch-down' PCR using M13 primers (Invitrogen Life Technologies, California); separated by agarose gel electrophoresis; the product bands were UV-visualized, and photo-documented.

\subsection{Reaction between GDH-Synthesized RNA and Total RNA}

GDH-synthesized RNA and total RNA preparations were normalized to a concentration of $5 \mu \mathrm{g} / \mu \mathrm{L}$ in $0.1 \mathrm{M}$ Tris- $\mathrm{HCl}$ buffer solution $\mathrm{pH}$ 8.0. The reactions were conducted in 8 numbered micro-centrifuge tubes placed on ice. Tube 1 contained $100 \mu \mathrm{g}$ of total RNA of control peanut, and $100 \mu \mathrm{g}$ of the

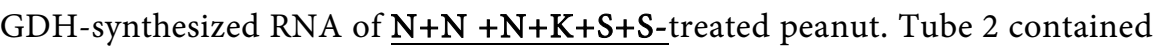
$200 \mu \mathrm{g}$ of total RNA of control peanut. Tube 3 contained $100 \mu \mathrm{g}$ of total RNA of $\mathrm{N}+\mathrm{P}+\mathrm{K}+\mathrm{K}+\mathrm{K}$-treated peanut and $100 \mu \mathrm{g}$ of the GDH-synthesized RNA of

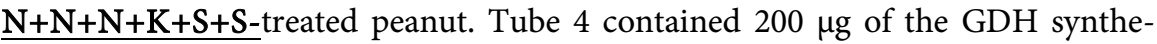
sized RNA of $\mathbf{N}+\mathbf{N}+\mathbf{N}+\mathbf{K}+\mathbf{S}+\mathbf{S}$-treated peanut. Tube 5 contained $100 \mu \mathrm{g}$ of the

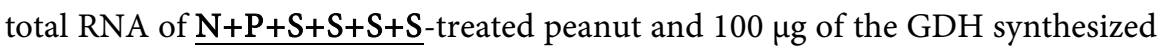
RNA of $\mathbf{N}+\mathrm{N}+\mathrm{N}+\mathrm{K}+\mathrm{S}+\mathrm{S}$-treated peanut. Tube 6 contained $200 \mu \mathrm{g}$ of the GDH

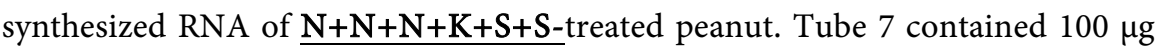
of the total RNA of $\mathrm{N}+\mathrm{P}+\mathrm{P}+\mathrm{P}$-treated peanut and $100 \mu \mathrm{g}$ of the GDH synthesized RNA of $\mathbf{N}+\mathrm{N}+\mathrm{N}+\mathrm{K}+\mathrm{S}+\mathrm{S}$-treated peanut. Tube 8 contained $200 \mu \mathrm{g}$ of the total RNA of control peanut. To each tube, $1 \mu \mathrm{L}$ of $0.6 \mathrm{mM}$ ribo-NTP mix was added; and the final volume of the reaction was brought to $50 \mu \mathrm{L}$ with $0.1 \mathrm{M}$ 
Tris- $\mathrm{HCl}$ buffer solution $\mathrm{pH}$ 8. Tubes $1,2,3,4,5$, and 7 were thermo-cycled: pre-heat $\left(96^{\circ} \mathrm{C}, 30 \mathrm{sec}\right)$. Then 40 cycles of cool $\left(5^{\circ} \mathrm{C}, 1 \mathrm{~min}\right)$, warm $\left(37^{\circ} \mathrm{C}, 2\right.$ $\min )$. Final storage $\left(5^{\circ} \mathrm{C}\right)$. Tubes 6 , and 8 were left on ice. The extent of reaction was demonstrated by $2 \%$ agarose gel electrophoresis of $7 \mu \mathrm{L}$ of each reaction solution. The gel was stained with ethidium bromide solution; and photographed. RNA band intensities were digitalized using UN-SCAN-IT gel digitalizing software (Silk Scientific, Inc., Orem, Utah, USA).

\subsection{Structural and Functional Characterization of RNAs}

To assign putative functions to the RNAs synthesized by GDH (RNA enzyme), their cDNA sequences were used as queries to search the NCBI nucleotide-nucleotide (excluding ESTs) BLAST (blastn) for peanut taxid 3818 database (Arachis hypogaea) [30]. Similarly, to identify the fragments of the cloned pCR4-TOPO vector DNA, the sequenced fragments were used as queries to search the NCBI nucleotide-nucleotide blastn. Putative functions were assigned to alignments with the highest scores, and in consideration of the molecular weight of the corresponding agarose gel electrophoresis bands of the PCR products. To compare sequence homologies among the GDH-synthesized RNAs, the NCBI BLASTN 2 Sequences alignment algorithm was used [31].

\subsection{DNA Physical Properties}

DNA sequences were applied to the Kibbe equations

(http://www.basic.northwestern.edu/biotools/oligocalc.html) to count the cytosines and guanines accurately and to calculate the $\mathrm{G}+\mathrm{C}$ contents, nearest neighbor, and melting temperatures (Tm) taking into account base stacking energy.

\section{Results and Discussion}

\subsection{G+C Contents and Amplification Uniformity}

Single product bands resulted from the PCR amplification of the insert cDNA of GDH-polymerized RNA (Figure 1), whereas multiple product bands resulted from the amplification of vector insert DNA (genetic code-based DNA), despite that the Tm applied in the "touch-down" PCR was stringent (Table 1), and the PCR protocol was conducted at the same time, with same cocktail of reagents, under same conditions. Therefore, there was amplification stability and uniformity for the cDNAs of GDH-synthesized RNA and amplification instability for the genetic code-based DNA. "Touchdown" PCR is recommended for circumventing incomplete priming [32] [33] [34], and for increased specificity and sensitivity in PCR amplification [35], but many of the recombinant plasmids (Figure 1 lanes $14,22,23,24,27$, and 29) with vector DNA inserts did not produce a main PCR product band thus suggesting that the chemistry of the insert vector fragment interfered with the complete melting dissociation of the DNA strands. Such incomplete melting dissociation of strands could arise from very 

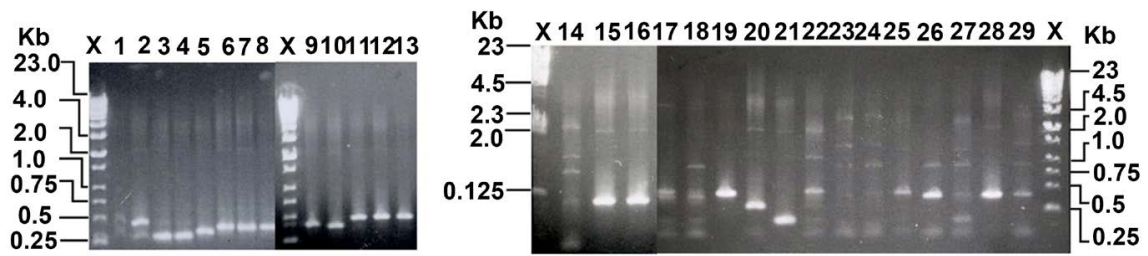

Figure 1. Polymerase chain reaction amplification of the cDNAs of GDH-synthesized RNA (nongenetic code-based) compared with that of genetic code-based DNA. The amplification was by touch-down PCR, after which equal aliquots were electrophoresed on $2 \%$ agarose gel containing ethidium bromide. The gel was photographed after electrophoresis. The cDNAs of GDH-synthesized RNA are lanes 1-13, 15-20. Genetic code-based DNAs are lanes 14, 21-29. $\mathrm{X}$ is DNA molecular weight marker.

Table 1. Some thermodynamic properties of the cDNA of GDH-synthesized RNA contrasted with those of genetic code-based (vector) DNA fragments.

\begin{tabular}{|c|c|c|c|c|c|}
\hline $\begin{array}{l}\text { Plasmid } \\
\text { Inserts }\end{array}$ & $\begin{array}{c}\text { Length } \\
\text { (base pairs) }\end{array}$ & GC Content \% & Nearest Neighbor ${ }^{\circ} \mathrm{C}$ & $\operatorname{Tm}$ basic $^{\circ} \mathrm{C}$ & Comment \\
\hline 1 & 143 & 57.0 & 84.92 & 83.7 & $\mathrm{~A}$ \\
\hline 2 & 313 & 35.5 & 79.86 & 77.3 & A \\
\hline 3 & 153 & 44.0 & 79.98 & 78.5 & A \\
\hline 4 & 153 & 51.0 & 82.27 & 81.4 & A \\
\hline 5 & 191 & 54.0 & 83.76 & 83.5 & A \\
\hline 6 & 243 & 50.0 & 84.49 & 82.5 & A \\
\hline 7 & 243 & 50.0 & 84.49 & 82.5 & A \\
\hline 8 & 243 & 50.0 & 84.49 & 82.5 & A \\
\hline 9 & 261 & 54.0 & 85.39 & 84.5 & A \\
\hline 10 & 241 & 49.8 & 84.45 & 82.5 & A \\
\hline 11 & 241 & 49.8 & 84.45 & 84.1 & A \\
\hline 12 & 334 & 52.0 & 84.98 & 84.1 & A \\
\hline 13 & 319 & 59.0 & 87.47 & 86.8 & A \\
\hline 14 & 146 & 59.0 & 86.18 & 84.4 & A \\
\hline 15 & 308 & 35.0 & 79.70 & 77.0 & A \\
\hline 16 & 312 & 35.3 & 79.88 & 77.2 & A \\
\hline 17 & 101 & 54 & 83.39 & 80.6 & A \\
\hline 18 & 69 & 55 & 78.24 & 77.7 & A \\
\hline 19 & 341 & 37 & 80.79 & 78.3 & A \\
\hline 20 & 121 & 55 & 82.99 & 82.0 & A \\
\hline 21 & 159 & 55 & 84.27 & 83.3 & B \\
\hline 22 & 302 & 50 & 85.17 & 83.3 & B \\
\hline 23 & 199 & 59.0 & 87.74 & 85.8 & B \\
\hline 24 & 365 & 50.7 & 86.28 & 84.0 & B \\
\hline 25 & 365 & 51.2 & 86.37 & 84.0 & B \\
\hline 26 & 188 & 59.0 & 87.74 & 85.8 & B \\
\hline 27 & 292 & 51.0 & 84.67 & 83.5 & B \\
\hline 28 & 166 & 59.0 & 86.18 & 84.4 & B \\
\hline 29 & 442 & 60.0 & 89.4 & 87.8 & $\mathrm{~B}$ \\
\hline
\end{tabular}

$\mathrm{a}=\mathrm{cDNA}$ of GDH-synthesized RNA (nongenetic code-based). $\mathrm{b}=$ genetic code-based DNA. 
high nearest neighbor stacking base interactions, and high $\mathrm{G}+\mathrm{C}$ compositions. The cDNAs of GDH-synthesized RNA varied their G+C contents broadly covering a range from $35 \%$ to $59 \%$, whereas the vector coding DNA fragments varied their $\mathrm{G}+\mathrm{C}$ contents for a narrower range from $50 \%$ to $60 \%$ (Table 1). Therefore, RNA synthesized by GDH is a modified RNA, its cDNA exhibiting chemical properties different from genetic code-based DNA.

The high $\mathrm{G}+\mathrm{C}$ contents of the vector DNA (Table 1) are in agreement with previous observations [20] [36] [37] [38] that the lengths of coding DNA segments in the genomes are under structural constraints associated with their higher $\mathrm{G}+\mathrm{C}$ contents compared with the poorer $\mathrm{G}+\mathrm{C}$ regions [39]. But high $\mathrm{G}+\mathrm{C}$ contents of DNA increase stability of genes [37]. Previous research on the importance of $\mathrm{G}+\mathrm{C}$ contents compared the $\mathrm{G}+\mathrm{C}$-rich with the $\mathrm{G}+\mathrm{C}$-poor regions [36] of genetic code-based DNA. The comparisons presented here between the $\mathrm{G}+\mathrm{C}$ contents of coding DNA sequence and the cDNA of GDH-synthesized RNA are at the base line for further unraveling of nucleic acid chemistry and function. Therefore, coding function imposed higher $\mathrm{G}+\mathrm{C}$ contents-related structural constraint on genome, whereas GDH synthesis of RNA minimized that $\mathrm{G}+\mathrm{C}$-related structural constraint.

The nearest neighbor interaction is a major factor that affects the stability of nucleic acid, the A.T pairing being always destabilizing [21]. The nearest neighbor effects increased the Tm values to the same extent for both the cDNAs of GDH-synthesized RNA and genetic code-based DNA inserts (Table 1). The wider range $(35 \%-59 \%)$ in the $\mathrm{G}+\mathrm{C}$ contents of the cDNAs of GDH-synthesized RNA compared with the narrower range $(50 \%-60 \%)$ in the vector DNA inserts suggests that cDNAs of GDH-synthesized RNA possess higher A+T contents which would destabilize at least some local sections in the double helix of the cDNAs. Local helical conformational changes have been reported to exercise biological functions [40]. Such relative difference in DNA stability may explain the uniformity of PCR amplification products for the cDNAs of GDH-synthesized RNA in contrast to the nonuniformity of the PCR products of vector DNA inserts (Figure 1). DNA polymerase could therefore be more active in the PCR of the cDNAs of GDH-synthesized RNA than in the genetic code-based vector DNA fragments.

It has been suggested that the RNA synthesized by GDH might function in the regulation of mRNA abundance through homologous sequence-mediated RNA interference activity [4] [6] [7]. In describing the features which are correlated with silencing efficiency, Chan et al. [16] identified the importance of low $\mathrm{G}+\mathrm{C}$-contents of the siRNA, suggesting that siRNA G+C-content negatively correlated with RNAi efficiency. Liu et al. [19] calculated that efficient siRNAs tend to be $\mathrm{A}+\mathrm{U}$-rich ( $\mathrm{G}+\mathrm{C}$ content is $44.0 \%$ to $47.8 \%$ ), whilst inefficient siR$\mathrm{NAs}$ tend to be $\mathrm{G}+\mathrm{C}$-rich (GC content is $52.7 \%$ to $55.2 \%$ ). The lower $\mathrm{G}+\mathrm{C}$-contents of the cDNAs of GDH-synthesized RNA (Table 1) explain the efficiency of GDH-synthesized RNA as siRNAs. The homologous target sequences 
in the mRNA for the binding of the GDH-synthesized RNA are also A+U-rich. Conversely, the higher G+C-contents of genetic code-based DNA (Table 1) could explain some of their inefficient siRNA activities [41]. The target sequences in the mRNA for the binding of the genetic code-based siRNA are also $\mathrm{G}+\mathrm{C}$-rich. Some publications have stated that the high $\mathrm{G}+\mathrm{C}$-contents of genetic code-based siRNA constructs may appear to be the stumbling block in the medical or pharmaceutical application of efficient siRNA technology compared with antisense technology [19] [42]. GDH-synthesized RNA helps to circumvent some of genetic code-based siRNA structural constraints because GDH implements the synthesis in response to the prevalent metabolic environment of the plant, tissue, and cells. We have modified the metabolic environment of several crop species and succeeded in knocking out specific toxic and anti-nutritional components [3] [4] [6] [9]. Also, mammalian GDH synthesizes RNA.

The differences between the G+C-contents of genetic code-based DNA and nongenetic code-based DNA (Table 1), and in the amplification uniformity of nongenetic code-based DNA (Figure 1) imply that genetic code-based DNA possess paramagnetic and electrostatic properties [22] [23] [24] that are different from those of nongenetic code-based DNA. Therefore, when GDH-synthesized RNA (the RNA enzyme) aligns in the correct orientation and interacts with its homologous mRNA (genetic code-based RNA) during silencing biochemical reaction, the force of the collusion between the different paramagnetic-dielectric RNA molecules could be so considerable that the resultant energy could liquefy total RNA, the lesser stable of the two types of RNA (Figure 2).

\subsection{Reaction between Genetic Code-Based RNA and Nongenetic Code-Based RNA}

The reactions between total RNA and the RNA synthesized by GDH resulted to total RNA degradation (Figure 2). Digital pixelated comparison of the extents of reactions in lanes 1 (Figure 2: reaction between total RNA of control peanut and

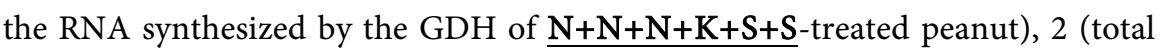
RNA of control peanut, after thermal cycling), 4 (RNA synthesized by the GDH

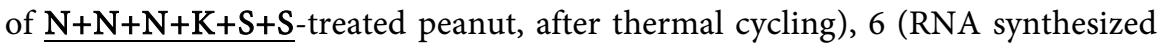

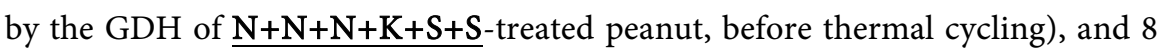
(total RNA of control peanut, before thermal cycling) showed that new molecular weight degraded bands lower than the 5S RNA band appeared in lane 1.

Comparison of lanes 3 (Figure 2: reaction between total RNA of

$\mathrm{N}+\mathrm{P}+\mathrm{K}+\mathrm{K}+\mathrm{K}$-treated peanut and RNA synthesized by the GDH of

$\mathrm{N}+\mathrm{N}+\mathrm{N}+\mathrm{K}+\mathrm{S}+\mathrm{S}$-treated peanut), 2 (total RNA of control peanut, after thermo-cycling), 4 (RNA synthesized by GDH of $\mathrm{N}+\mathrm{N}+\mathrm{N}+\mathrm{K}+\mathrm{S}+\mathrm{S}$-treated peanut, af-

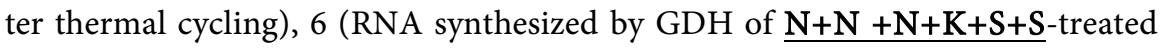
peanut, before thermal cycling), and 8 (total RNA of untreated control peanut, before thermal cycling) also showed the emergence of new degraded RNA bands between the $16 \mathrm{~S}$ and $5 \mathrm{~S}$ rRNA bands that were absent from the GDH-synthesized RNA and total RNA in lane 3. 
Interaction Between Total RNA and GDH-synthesized RNA

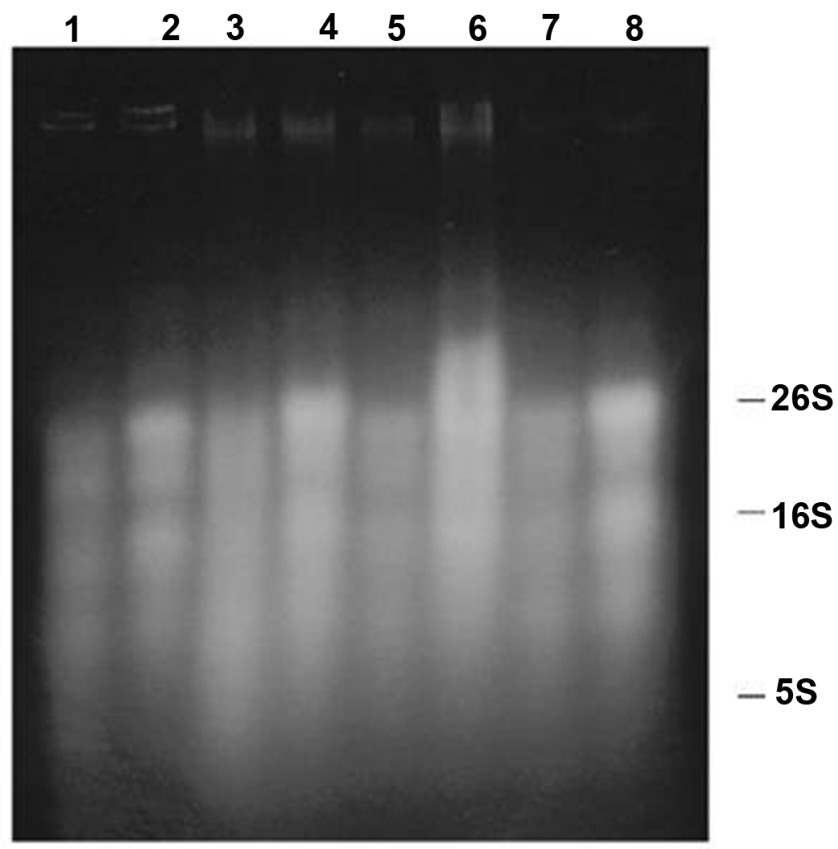

Figure 2. In vitro reaction between GDH-synthesized RNA and total RNA. The GDH-synthesized RNA enzyme activity was demonstrated in 8 test tubes. Reaction 1 (lane1) is total RNA of control peanut mixed with the GDH-synthesized RNA of $\mathrm{N}+\mathrm{N}+\mathrm{N}+\mathrm{K}+\mathrm{S}+\mathrm{S}$-treated peanut. Reaction 2 (lane 2) is control's total RNA. Reaction 3 (lane 3 ) is total RNA of $\mathrm{N}+\mathrm{P}+\mathrm{K}+\mathrm{K}+\mathrm{K}$-treated peanut mixed with the GDH-synthesized RNA of $\mathrm{N}+\mathrm{N}+\mathrm{N}+\mathrm{K}+\mathrm{S}+\mathrm{S}$-treated peanut. Reaction 4 (lane 4 ) is the GDH-synthesized RNA of $\mathrm{N}+\mathrm{N}+\mathrm{N}+\mathrm{K}+\mathrm{S}+\mathrm{S}$-treated peanut. Reaction 5 (lane 5) is the total RNA of $\mathrm{N}+\mathrm{P}+\mathrm{S}+\mathrm{S}+\mathrm{S}+\mathrm{S}$-treated peanut mixed with the $\mathrm{GDH}$-synthesized RNA of $\mathrm{N}+\mathrm{N}+\mathrm{N}+\mathrm{K}+\mathrm{S}+\mathrm{S}$-treated peanut. Reaction 6 (lane 6) is the GDH-synthesized $\mathrm{RNA}$ of $\mathrm{N}+\mathrm{N}+\mathrm{N}+\mathrm{K}+\mathrm{S}+\mathrm{S}$-treated peanut. Reaction 7 (lane 7) is the total $\mathrm{RNA}$ of $\mathrm{N}+\mathrm{P}+\mathrm{P}+\mathrm{P}$-treated peanut mixed with the $\mathrm{GDH}$-synthesized RNA of $\mathrm{N}+\mathrm{N}+\mathrm{N}+\mathrm{K}+\mathrm{S}+\mathrm{S}$-treated peanut. Reaction 8 (lane 8 ) is the total RNA of control peanut. Reactions 1, 2, 3, 4, 5, and 7 were thermo-cycled; reactions 6 and 8 were not. After reaction, equal aliquots of reactions were electrophoresed ( $2 \%$ agarose gel), then the gel was photographed.

Similarly, reaction 5 (Figure 2: lane 5) between the total RNA of

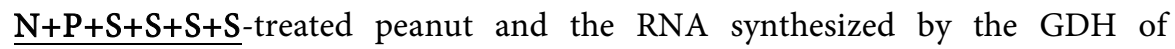
$\mathrm{N}+\mathrm{N}+\mathrm{N}+\mathrm{K}+\mathrm{S}+\mathrm{S}$-treated peanut demonstrated the considerable loss of RNA bands compared with the controls (lanes 2, 4, 6, and 8).

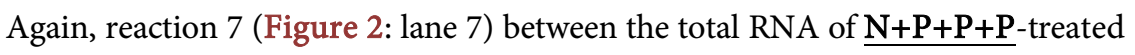
peanut and the RNA synthesized by the GDH of $\mathbf{N + N + N + K + S + S}$-treated peanut displayed a vivid loss of RNA bands compared with the controls (lanes 2, 4, 6 , and 8).

The reactions depicted in lanes $1,3,5$, and 7 in the absence of protein enzymes suggested that the GDH-synthesized RNA acted as enzyme to degrade transcripts that shared sequence homologies with it because comparison of lanes 
2 and 8 showed that the thermal cycling did not degrade total RNA, but lanes 4 and 6 showed that GDH-synthesized RNA was sensitive to thermal cycling, the high molecular weight bands above 26S rRNA in lane 6 being absent after thermal cycling (lane 4) which could have resulted from their thermal instability due to the high $\mathrm{A}+\mathrm{U}$ content of GDH-synthesized RNA (Table 1). The thermal cycling temperatures applied in this study did not exceeded $37^{\circ} \mathrm{C}$ in order to avoid RNA H-bond breakage during the RNA degradation reaction. The cooling of reaction temperature to $5^{\circ} \mathrm{C}$ was designed to allow the GDH-synthesized RNA to align with homologous sequences in total RNA moieties. Temperature was raised to $37^{\circ} \mathrm{C}$ to allow RNA degradation reaction to occur. This suggests there could be chemical interactions in the alignment of homologous RNA sequences. Meyer [14], DiChiacchio et al. [13] applied computational methods to uncover possible interactions between two RNA molecules. Reactions (Figure 2) were thermo-cycled between $5^{\circ} \mathrm{C}$ and $37^{\circ} \mathrm{C}$ to increase the rate of homologous sequence alignment, total RNA degradation rate, and to continuously disaggregate the reaction products from the surfaces of the RNA enzyme. We seeded the reactions (Figure 2) by addition of ribo-nucleoside triphosphates to the reaction mix in order to displace the position of equilibrium further to the right.

The results (Figure 2) were obtained by cross-over reaction between total RNA from a treated peanut and the RNA synthesized by the GDH from a differently treated peanut. When the total RNA and the GDH-synthesized RNA were from the same treatment of peanut, there were no reactions (results not shown). This suggested that the total RNA population in peanut is in steady state relationship with the mechanisms that regulate the synthesis of RNA by the prevalent GDH isoenzymes. This is the biochemical basis of the production of plant metabolic variants (phenotypes) at will, via induction of GDH synthesis of RNA [4] [7] [8] [9] [26].

Again, the molecular responses of the different total RNAs of peanut to the same GDH-synthesized RNA (lanes 1, 3, 5, and 7) were different, further suggesting that each mRNA profile of the total RNAs was for a specific metabolic phenotype/variant [4].

Therefore, the cross-over reactions (Figure 2) were the in vitro demonstration of the in vivo degradation of transcripts by the GDH-synthesized RNA. It could be, but without knowing it, that the biochemical mechanism underlying the experimentations involving the treatments of whole plants, seedlings, organs, tissues or cell cultures with solutions of nucleophiles, electrophiles, mineral fertilizers, N-carboxymethyl chitosan, biochemical regulators, and agricultural chemicals are the induction of GDH-synthesized RNA enzyme activity to degrade the set of homologous mRNA as in Figure 2. And, the molecular responses of plant metabolism to the environment is a huge discipline area of plant enzymology and molecular biology research that is important to scientific investigations in plant systems, crop production, forestry, natural and environmental resources management, and horticulture. RNA as enzyme has been demonstrat- 
ed in the splicing process [10] [43] [44] but not in the regulation of mRNA abundance through degradation by nongenetic code-based RNA.

\subsection{Biochemical Synthesis of $\mathrm{G}+\mathrm{C}$ and $\mathrm{A}+\mathrm{U}$ Contents of RNA}

In vitro demonstration of the function of GDH-synthesized RNA as enzyme begets a conversation on the structure of the RNA (Table 2 and Table 3). The RNA oligonucleotides synthesized by each GDH hexameric isoenzyme illuminated the chemical frequency of $\mathrm{G}+\mathrm{C}$ contents because instead of comparing the isoelectric point ( $\mathrm{pI}$ ) values of the polypeptides, GDH biological function is visualized in terms of nucleic acid sequence repeats and homologies (Table 2) similar to genetic code sequence repeats. GDH has a non-allelic gene structure consisting of three different subunit polypeptides [1]. The gene $\left(\mathrm{GDH}_{1}\right)$ encoding the more acidic subunits ( $\mathrm{a}$, and $\alpha$ ) is heterozygous, and co-dominant; and the gene $\left(\mathrm{GDH}_{2}\right)$ encoding the less acidic subunit $(\beta)$ is homozygous. The binomial distribution pattern of the 28 hexameric isoenzymes [45] is a protein population array that displays the subunit relationships on the native polyacrylamide gel landscape. The purification of active GDH isoenzymes from the slab of native acrylamide gel was made possible by the subzero electrophoretic fractionation processes that preserved the structural integrity and catalytic function of each hexameric isomer. Systematic pair-wise sequence homology comparisons [31] showed that the RNA (\#19) synthesized by GDH $\beta 6$ homo-hexameric isoenzyme did not share sequence match with the RNA (\#18) synthesized by GDH a6 homo-hexameric isoenzyme, and did not share sequence match with the RNA (\#17) synthesized by GDH a6 homo-hexameric isoenzyme (Table 2 and Table 3). This is surprising because the three subunit polypeptides (a, $\alpha$, and $\beta$ ) of the enzyme share common antigenic properties [26]. However, the RNA (\#18) synthesized by GDH a6 homo-hexamer shared three-fold homology matches with the RNA (\#17) synthesized by GDH $a 6$ homo-hexameric isoenzyme. Global homology comparisons of the GDH-synthesized RNAs (Table 2) of $\mathrm{N}+\mathrm{N}+\mathrm{N}+\mathrm{K}+\mathrm{S}+\mathrm{S}$-treated peanut showed that most were synthesized by hexameric isoenzymes that consisted of mixed ratios of a-subunit and $\alpha$-subunit polypeptides; and less frequency of RNAs synthesized by mixed isoenzymes that consisted of the three subunit polypeptides. The RNAs synthesized by nucleotide-treated peanuts were more complicated in their primary structure because almost all of the 28 hexameric isoenzymes of GDH were induced [1]. Therefore, the repeated plus/plus and plus/minus sequence codes (alignments) among the GDH-synthesized oligonucleotide RNAs (Table 2) appear to be reminiscent of the possible rudiments of nucleic acid biological codes. Global homology comparisons (Table 2) also revealed that all the RNAs with low $\mathrm{G}+\mathrm{C}$ contents were synthesized by the GDH $\beta 6$ homo-hexameric isoenzyme. Conversely, all the RNAs with high $\mathrm{G}+\mathrm{C}$ contents were synthesized by the GDH hexameric isoenzymes enriched in a-subunit and/or a-subunit polypeptides. Therefore, in the polymerization of ribo-nucleoside triphosphates to produce RNA enzyme, the 
Table 2. Binomial statistical sequence homologies of some RNAs synthesized by hexameric (a6, $\alpha 6, \beta 6$ etc.) isoenzymes of Peanut glutamate dehydrogenase.

\begin{tabular}{|c|c|c|c|c|c|c|c|c|c|c|c|c|c|c|}
\hline $\begin{array}{l}\text { GDH } \\
\text { RNA }\end{array}$ & $\begin{array}{c}19 \\
(\beta 6)\end{array}$ & $\begin{array}{c}18 \\
(\mathrm{a} 6)\end{array}$ & 8 & 4 & 13 & 20 & 1 & 5 & 7 & 10 & 9 & 15 & 16 & 2 \\
\hline $\begin{array}{c}19 \\
(\beta 6)\end{array}$ & --- & no match & $\begin{array}{c}\text { no } \\
\text { match }\end{array}$ & $\begin{array}{c}\text { no } \\
\text { match }\end{array}$ & $\begin{array}{c}\text { no } \\
\text { match }\end{array}$ & $\begin{array}{c}\text { no } \\
\text { match }\end{array}$ & $\begin{array}{l}+/- \\
\text { match }\end{array}$ & $\begin{array}{c}\text { no } \\
\text { match }\end{array}$ & $\begin{array}{l}\text { no } \\
\text { match }\end{array}$ & $\begin{array}{c}\text { no } \\
\text { match }\end{array}$ & $\begin{array}{l}\text { no } \\
\text { match }\end{array}$ & $\begin{array}{c}+/+ \\
\text { match }\end{array}$ & $\begin{array}{l}+/- \\
\text { match }\end{array}$ & $\begin{array}{c}+/+ \\
\text { match }\end{array}$ \\
\hline $\begin{array}{c}17 \\
(a 6)\end{array}$ & $\begin{array}{c}\text { no } \\
\text { match }\end{array}$ & $\begin{array}{c}3+/+ \\
\text { matches }\end{array}$ & $\begin{array}{c}6+/+ \\
\text { matches }\end{array}$ & $\begin{array}{c}5+/+ \\
\text { matches }\end{array}$ & $\begin{array}{c}4+/- \\
\text { matches }\end{array}$ & $\begin{array}{c}3+/+ \\
\text { matches }\end{array}$ & $\begin{array}{c}6+/+ \\
\text { matches }\end{array}$ & $\begin{array}{c}4+/+ \\
\text { matches }\end{array}$ & $\begin{array}{c}4+/+ \\
\text { matches }\end{array}$ & $\begin{array}{c}4+/+ \\
\text { matches }\end{array}$ & $\begin{array}{c}4+/+ \\
\text { matches }\end{array}$ & $\begin{array}{c}\text { no } \\
\text { match }\end{array}$ & $\begin{array}{c}\text { no } \\
\text { match }\end{array}$ & $\begin{array}{c}\text { no } \\
\text { match }\end{array}$ \\
\hline $\begin{array}{c}18 \\
(\mathrm{a} 6)\end{array}$ & $\begin{array}{c}\text { no } \\
\text { match }\end{array}$ & --- & $\begin{array}{c}4+/+ \\
\text { matches }\end{array}$ & $\begin{array}{c}4+/+ \\
\text { matches }\end{array}$ & $\begin{array}{c}3+/- \\
\text { matches }\end{array}$ & $\begin{array}{c}3+/+ \\
\text { matches }\end{array}$ & $\begin{array}{c}4+/+ \\
\text { matches }\end{array}$ & $\begin{array}{c}3+/+ \\
\text { matches }\end{array}$ & $\begin{array}{c}4+/- \\
\text { matches }\end{array}$ & $\begin{array}{c}4+/- \\
\text { matches }\end{array}$ & $\begin{array}{c}6+/- \\
\text { matches }\end{array}$ & $\begin{array}{c}\text { no } \\
\text { match }\end{array}$ & $\begin{array}{c}\text { no } \\
\text { match }\end{array}$ & $\begin{array}{c}\text { no } \\
\text { match }\end{array}$ \\
\hline 15 & $\begin{array}{l}+/+ \\
\text { match }\end{array}$ & no match & $\begin{array}{c}\text { no } \\
\text { match }\end{array}$ & & & & & & & & & & $\begin{array}{l}+/- \\
\text { match }\end{array}$ & \\
\hline 16 & $\begin{array}{l}+/- \\
\text { match }\end{array}$ & no match & $\begin{array}{c}\text { no } \\
\text { match }\end{array}$ & & & & & & & & & & & \\
\hline 4 & $\begin{array}{c}\text { no } \\
\text { match }\end{array}$ & $\begin{array}{c}4+/+ \\
\text { matches }\end{array}$ & $\begin{array}{c}4+/+ \\
\text { matches }\end{array}$ & & & & & & & & & & & \\
\hline 5 & $\begin{array}{c}\text { no } \\
\text { match }\end{array}$ & $\begin{array}{c}3+/+ \\
\text { matches }\end{array}$ & $\begin{array}{c}3+/+ \\
\text { matches }\end{array}$ & & & & & & & & & & & \\
\hline 2 & $\begin{array}{c}+/+ \\
\text { match }\end{array}$ & no match & $\begin{array}{c}\text { no } \\
\text { match }\end{array}$ & & & & & & & & & & & \\
\hline 1 & $\begin{array}{c}+/- \\
\text { match }\end{array}$ & $\begin{array}{c}4+/+ \\
\text { matches }\end{array}$ & $\begin{array}{c}4+/+ \\
\text { matches }\end{array}$ & & & & & & & & & & & \\
\hline 20 & $\begin{array}{c}\text { no } \\
\text { match }\end{array}$ & $\begin{array}{c}3+/+ \\
\text { matches }\end{array}$ & $\begin{array}{c}7+/+ \\
\text { matches }\end{array}$ & & & & & & & & & & & \\
\hline 10 & $\begin{array}{c}\text { no } \\
\text { match }\end{array}$ & $\begin{array}{c}4+/- \\
\text { matches }\end{array}$ & $\begin{array}{c}\text { no } \\
\text { match }\end{array}$ & & & & & & & & & & & \\
\hline
\end{tabular}

$\beta 6$ homo-hexameric GDH isomer selected ribo-ATP and UTP preferentially as substrates; whereas the $\alpha 6$, a6 and combinations thereof selected ribo-GTP and ribo-CTP preferentially as substrates. These biochemical considerations give strength to the repeatedly published over whelming preponderance of $\mathrm{G}+\mathrm{C}$-rich regions as against the lesser frequency of the $\mathrm{A}+\mathrm{T}$-rich regions in the genome [20] [36] [37]. GDH hexameric isoenzymes are being applied routinely for the synthesis of nucleic acid hybridization probes for studying the biochemical pathways of the recalcitrant medicinal plants, Phyla dulcis [9] [46]. Studies which applied genetic code-based hybridization probes instead [47] did not knock out the mRNAs encoding the monoterpene synthases, whereas studies with hybridization probes based on GDH-synthesized RNA enzyme have knocked out the mRNAs encoding the monoterpene synthases (Osuji unpublished results). This illustrates the efficiency of GDH-synthesized RNA enzyme.

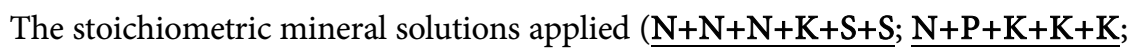

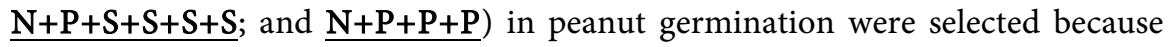
they were among those that did not delay the emergence of seedling radicle compared with water treatment. There are 299 stoichiometric combinations of mineral macronutrients that mimic the hexameric subunit structure of GDH. We have planted peanut seeds in the month of May in the tissue culture chamber, 
Table 3. Some cDNA inserts and genetic code-based (vector) DNA inserts.

\section{Plasmid 1: cDNA insert}

Arachis hypogaea oxalate oxidase (OxOxl) mRNA, EU024476.1

TGAGTCCTGACCGATAGCGCCAATGCGTTGAGTACCTTCAACGCCAAGAACGTCAACTACCAGCGCACGCCGCACTTCAAGAACAAA CCCGGCACGCGGCATAGCGATGAGTCCTGACCGGGTACGCAGTCTACGAGACCAGTA.

Plasmid 2: cDNA insert

Arachis hypogaea profilin (Ara h5) mRNA AF059616.1

GATTTTATTTAGGAGGTATTGGGAACGAATTGGAATGTAATAATATTGATTCATAGAGATCCAGAAGAAAAAGAATAATCTTCTACTT TGAGAATAATAAAAAAAGAAAAGTGTTCAATTGGAACATGAAAACGTGACCTGACTGAATACTGGTCTCGTAGACTGCGTACCCGGT CAGGACTCATCGCTACGTTAGCGTCTCTGAGGCGCGCTATTCTACAATCTTAAAAACCCCTGTCAACCCTTTAAATTGCTTTTAAGAC AATGATTTGCGCTTCTTTCTGATTTCTTCTTGGGGAGAAGAAACCCGTGGGCTGACGTTGCTGCGGGGCGCACTTTACAAGCCTTTGC CTTACAGTTCAACGCCCTATCGGTCAGGACTCATAAGGGC

Plasmid 3: cDNA insert

Arachis hypogaea ubiquitin-conjugating enzyme (UBC) mRNA, AY769917.2

GAGTCCTGACCGATAGTGAATAGGTCGTTGTGTTTCATGAGGCCTCCTTGATACTCATGAACTACAGATATTTGACGTCAAAAATAAT TCAAATAAGTTGTCCGACAATGCTGATGAGTCCTGACCGGGTACGCAGTCTACGAGACCAGTAAG

Plasmid 4: cDNA insert

Arachis hypogaea type 2 metallothionein (MT2d) mRNA, DQ665256.1

GAGTCCTGACCGATAGGAGATCAAGGCACCCCATGTCTTGAGGGTGGGACGGTTATTTGCTCAGGATAATAAAGGGCGGTTTCAGTT CAAAGTGCCTGAGCTTAGTATAGCGATGAGTCCTGACTGGGTACGCAGTCTACGAGACCAGTAAGG

Plasmid 5: cDNA insert

Arachis hypogaea mRNA for ABA 8'-hydroxylase (CYP707A2 gene), cultivar Yueyou 7, mRNA HG764751.1

GAGTCCTGACCGATAGCGGCCTGCATGCTCATGTTGCCAGTCTTGCCACCAGTACCCGTTCCAGTGTCAGGAGCCGGGAACTGACCT ACGCCATTTTTGTAAACACCGGTAGAAGAGGAATAAGGACTCCCGGAAGTGTGCCAAGTCACCAAGGTTTCAACTTCGGGTACGCAG TCTACGAGACCAGTAAG

Plasmid 8: cDNA insert

Arachis hypogaea cultivar fuhua 8 glutamate dehydrogenase 1 (GDH1) mRNA, KT933119.1 ACTGGTCTCGTAGACTGCGTACCCGGTCAGGACTCATCGCTACGTTAGCGTCTCTGAGGCGCGCTATTCTACAATCTTAAAAAC CCCTGTCAACCCTTTAAATTGCTTTTAAGACAATGATTTGCGCTTCTTTCTGATTTCTTCTTGGGGAGAAGAAACCCGTGGGCTG ACGTTGCTGCGGGGCGCACTTTACAAGCCTTTGCCTTACAGTTCAACGCCCTATCGGTCAGGACTCATAAGGGC

Plasmid 9: cDNA insert.

Arachis hypogaea strain E2-4-83-12 delta-12 fatty acid desaturase (FAD2B) gene, JN544190.1

TGAGTCCTGACCGATAGCCTGCCTAAACCTTCTTGAAGTAGTGGCGGCGGTCGTTTTCGGTGACTGTCTGCTGGAAAATGTCCG TCCAGAAATCCCGCTCCATTACGTCCTGGTGAAACATCACCCCGCAGATAACCTCCATCGGGTTGCACTTCAAAAGCTCGGCAA CCTTCACGGCCTGCTTGACGCTCATTTCATGTTTTCCCGCCTTCTGTAGCGATGAGTCCTGACCGGGTACGCAGTCTACGAGACC AGTAAGGG

Plasmid 10 cDNA Insert.

Arachis hypogaea cultivar fuhua 8 glutamate dehydrogenase 1 (GDH1) mRNA, Sequence ID: KT933119.1 CTGGTCTCGTAGACTGCGTACCGGGTCAGGACTCATCGCTACGTTAGCGTCTCTGAGGCGCGCTATTCTACAATCTTAAAAACC CCTGTCAACCCTTTAAATTGCTTTTAAGACAATGATTTGCGCTTCTTTCTGATTTCTTCTTGGGGAGAAGAAACCCGTGGGCTGA CGTTGCTGCGGGGCGCACTTTACAAGCCTTTGCCTTACAGTTCAACGCCCTATCGGTCAGGACTCATAAGGG

Plasmid 11: cDNA insert.

Arachis hypogaea cultivar JL24 phenylalanine ammonia-lyase (PAL) mRNA, GU477587.1

ACTGGTCTCGTAGACTGCGTACCCGACTAGTGAGCTATTACGCTTTCTTTAAAGGGTGGCTGCTTCTAAGCCAACCTCCTAGCTGTCT AAGCCTTCCCACATCGTTTCCCACTTAACCATAACTTTGGGACCTTAGCTGACGGTCTGGGTTGTTTCCCTTTTCACGACGGACGTTA GCACCCGCCGTGTGTCTCCCATGCTCGGCACTTGTAGGTATTCGGAGTTTGCATCGGTTTGGTAAGTCGGGATGACCCCCTAGCCGA AACAGTGCTCTACCCCCTACAGTGATACATGAGGCGCTACCTAAATAGCTATCGGTCAGGACTCATAAGGG

Plasmid 12: cDNA insert

Arachis hypogaea cultivar JL24 phenylalanine ammonia-lyase (PAL) mRNA,ID: GU477587.1

TGGTCTCGTAGACTGCGTACCCGACTAGTGAGCTATTACGCTTTCTTTAAAGGGTGGCTGCTTCTAAGCCAACCTCCTAGCTGTCTAA GCCTTCCCACATCGTTTCCCACTTAACCATAACTTTGGGACCTTAGCTGACGGTCTGGGTTGTTTCCCTTTTCACGACGGACGTTAGC ACCCGCCGTGTGTCTCCCATGCTCGGCACTTGTAGGTATTCGGAGTTTGCATCGGTTTGGTAAGTCGGGATGACCCCCTAGCCGAAA CAGTGCTCTACCCCCTACAGTGATACATGAGGCGCTACCTAAATAGCTATCGGTCAGGACTCATAAGGG 


\section{Continued}

Plasmid 13: cDNA insert

Arachis hypogaea beta-ketoacyl-ACP synthetase II-like (KASII) mRNA, FJ358425.1

CTGGTCTCGTAGACTGCGTACCCGACTAACCCATGTGCAAGTGCCGTTCACATGGAACCTTTCCCCTCTTCGGCCTTCAAAGTTCTCA TTTGAATATTTGCTACTACCACCAAGATCTGCACCGACGGCCGCTCCGCCCGGGCTCGCGCCCCAGGTTTTGCAGCGACCGCCGCGC CCTCCTACTCATCGCGGCATAGCCCTTGCCCCGACGGCCGGGTATAGGTCACGCGCTTCAGCGCCATCCATTTTCGGGGCTAGTTGAT TCGGCAGGTGAGTTGTTACACACTCCTTAGCGGATGTCGGTCAGGACTCATAAGGG

\section{Plasmid 14: vector DNA insert}

gnl|uv|U37573.1:2706-4083 Phagemid vector pBK-CMV (+/-homology)

GGGCGAAGTGCCGGGGCAGGATCTCCTGTCATCTCACCTTGCTCCTGCCGAGAAAGTATCCATCATGGCTGATGCAATGCGGCGGCT GCATACGCTTGATCCGGCTACCTGCCCATTCGACCACCAAGCGAAACATCGCATCGAGC.

Plasmid 15:cDNA insert

Arachis hypogaea profilin (Ara h 5) mRNA: AF059616.1

GGATTTTATTTAGGAGGTATTGGGAACGAATTGGAATGTAATAATATTGATTCATAGAGATCCAGAAGAAAAAGAATAATCTTC TACTTTGAGAATAATAAAAAAAGAAAAGTGTTCAATTGGAACATGAAAACCGTGACCTGACTGAATTAGTTCTCGTTATTTTTA GGGAAGGAGTGGAGATTATCGAACGAAGGATCCAATTACTTCGAAAGAATTGAACGAGGAGCCGTATGAGGTGAAAATCTCAT GTACGGTTCTGTAGAGTGGCAGTAAGGATGACTTATCTGTCAACTTTTCCACTATTA

\section{Plasmid 16: cDNA insert}

Arachis hypogaea mitogen-activated protein kinase 2 mRNA, DQ068453.1

TAATAGTGGAAAAGTTGACAGATAAGTCATCCTTACTGCCACTCTACAGAACCGTACATGAGATTTTCACCTCATACGGCTCCTCGTT CAATTCTTTCGAAGTAATTGGATCCTTCGTTCGATAATCTCCACTCCTTCCCTAAAAATAACGAGAACTAATTCAGTCAGTCACGTTT TCATGTTCCAATTGAACACTTTTCTTTTTTTATTATTCTCAAAGTAGAAGATTATTCTTTTTCTTCTGGATCTCTATGAATCAATATTAT TACATTCCAATTCGTTCCCAATACCTCCTAAATAAAATCCAAGGGC

\section{Plasmid 17 cDNA insert}

Arachis hypogaea ethylene-responsive element binding factor 1 (ERF1) mRNA, JQ048930.1

GAGTCCTGACCGAGAACGGCATTGATAGCGATGAGTCCTGACCGACAACGGCATTGATAGCGATGAGTCCTGACCGGGTACGC AGTCTACGAGACCAGTAA

Plasmid 18 cDNA insert

Arachis hypogaea triacylglycerol lipase 1 mRNA, GU902981.1:

TGAGTCCTGACCGACAACGGCATTGATAGCGATGAGTCCTGACCGGGTACGCAGTCTACGAGACCAGTA

\section{Plasmid 19 cDNA insert}

Arachis hypogaea mitogen-activated protein kinase 2 mRNA:

DQ068453.1GATTTTATTTAGGAGGTATTGGGAACGAATTGGAATGTAATAATATTGATTCATAGAGATCCAGAAGAAAAAGAAT AATCTTCTACTTTGAGAATAATAAAAAAAGAAAAGTGTTCAATTGGAACATGAAAACGTGACTGACTGAATTAGTTCTCGTTAT TTTTAGGGAAGGAGTGGAGATTATCGAACGAAGGATCCAATTACTTCGAAAGAATTGAACGAGGAGCCGTATGAGGNGAAAAT CTCATGTACGGTTCTGTACAGTGGCAGTAAGGATGACTTATCTGTCAACTTTTNCACTATTACAAGGGCNAATTCGCGGCCNGT NAATCCAATTCGCC

Plasmid 20: cDNA insert

Arachis hypogaea arachin Ahy-3 mRNA, AY722687.1

GTCCTGACCGAGAACGGCATTGATAGCGATGAGTCCTGACCGACAACGGCATTGATAGCGATGAGTCCTGACCGACAACGGCATTGA TAGCGATGAGTCCTGACCGGGTACGCAGTCTACG

\section{Plasmid 21: vector DNA insert}

gnl|uv|J01636.1:1-7477 E.coli lactose operon with lacI, lacZ, lacY and lacA genes.

CGTCGTGACTGGGAAAACCCTGGCGTTACCCAACTTAATCGCCTTGCAGCACATCCCCCTTTCGCCAGCTGGCGTAATAGCGAAGAG GCCCGCACCGATCGCCCTTCCCAACAGTTGCGCAGCCTATACGTACGGCAGTTTAAGGTTTACACCTATA

Plasmid 22: Vector DNA insert

gnl|uv|J01749.1:1-4361-49 Cloning vector pBR322

TAAAGTATATATGAGTAAACTTGGTCTGACAGTTACCAATGCTTAATCAGTGAGGCACCTATCTCAGCGATCTGTCTATTTCGTTCAT CCATAGTTGCCTGACTCCCCGTCGTGTAGATAACTACGATACNGGGAGGGCTTACCATCTGGCCCCAGTGCTGCAATGATACCGCGA GACCCACGCTCACCGGCTCCAGATTTATCAGCAATAAACCAGCCAGCCGGAAGGGCCGAGCGCAGAAGTGGTCCTGCAACTTTATCC GCCTCCATCCAGTCTATTAATTGTTGCCGGGAAGCTAGAG 


\section{Continued}

\section{Plasmid 23: Vector DNA insert}

gnl|uv|U37573.1:2706-4083 Phagemid vector pBK-CMV

CTCCTGCCGAGAAAGTATCCATCATGGCTGATGCAATGCGGCGGCTGCATACGCTTGATCCGGCTACCTGCCCATTCGACCACCAAG CGAAACATCGCATCGAGCGAGCACNGTACTCGGATGGAAGCCGGTCTTGTCGATCAGGATGATCTGGACGAAGAGCATCAGGGGCT CGCGCCAGCCGAACTGTTCGCCAGGC

\section{Plasmid 24: Vector DNA insert}

gnl|uv|AF028837.1:1577-1628 Cloning vector pKILHIS-1

TGCCTGCTTGCCGAATATCATGGTGGAAAATGGCCGCTTTTCTGGATTCATCGACTGTGGCCGGCTGGGTGTGGCGGACCGCTATCA GGACATAGCGTTGGCTACCCGTGATATTGCTGAAGAGCCTTGGCGGCGAATGGGCNTGACCGCTTCCTCGTGCTTTACGGTATCGCC GCTCCCGATTCGCAGCGCATCGCCTTCTATCGCCTTCTTGACGAGTTCTTCTGAATTATTAACGCTTACAATTTCCTGATGCGGTATTT TCTCCTTACGCATCTGTGCGGTATTTCACACCGCATCAGGTGGCACTTTTCGGGGAAATGTGCGCGGAACCCCTATTTGTTTATTTTT CTAAATACATTCAA

\section{Plasmid 25: Vector DNA insert}

gnl|uv|X65311.2:2262-2409 Cloning vector pGEM-7Zf(-)

GCGATGCCTGCTTGCCGAATATCATGGTGGAAAATGGCCGCTTTTCTGGATTCATCGACTGTGGCCGGCTGGGTGTGGCGGACCGCT ATCAGGACATAGCGTTGGCTACCCGTGATATTGCTGAAGAGCCTTGGCGGCGAATGGGCTGACCGCTTCCTCGTGCTTTACGGTATC GCCGCTCCCGATTCGCAGCGCATCGCCTTCTATCGCCTTCTTGACGAGTTCTTCTGAATTATTAACGCTTACAATTTCCTGATGCGGT ATTTTCTCCTTACGCATCTGTGCGGTATTTCACACCGCATCAGGTGGCACTTTTCGGGGAAATGTGCGCGGAACCCCTATTTGTTTAT TTTTCTAAATACATT

\section{Plasmid 27: Vector DNA insert}

gnl|uv|NGB00350.1:415-785 Invitrogen pZErO-2 vector multiple cloning site TCGTCTGTTTGTGGATGTACAGAGTGATATTATTGACACGCCGGGGCGACGGATGGTGATCCCCCTGGCCAGTGCACGTCTGCTGTC AGATAAAGTCTCCCGTGAACTTTACCCGGTGGTGCATATCGGGGATGAAAGCTGGCGCATGATGACCACCGATATGGCCAGTGTGCC GGTCTCCGTTATCGGGGAAGAAGTGGCTGATCTCAGCCACCGCGAAAATGACATCAAAAACGCCATTAACCTGATGTTCTGGGGAAT ATAAATGTCAGGCATGAGATTATCAAAAAGG

\section{Plasmid 29: vector DNA insert}

gnl|uv|U37573.1:2706-4083 Phagemid vector pBK-CMV

GGGCGAAGTGCCGGGGCAGGATCTCCTGTCATCTCACCTTGCTCCTGCCGAGAAAGTATCCATCATGGCTGATGCAATGCGGCGGCT GCATACGCTTGATCCGGCTACCTGCCCATTCGACCACCAAGCGAAACATCGCATCGAGCGAGCACGTACTCGGATGGAAGCCGGTCT TGTCGATCAGGATGATCTGGACGAAGAGCATCAGGGGCTCGCGCCAGCCGAACTGTTCGCCAGGCTCAAGGCGAGCATGCCCGACG GCGAGGATCTCGTCGTGACCCATGGCGATGCCTGCTTGCCGAATATCATGGTGGAAAATGGCCGCTTTTCTGGATTCATCGACTGTG GCCGGCTGGGTGTGGCGGACCGCTATCAGGACATAGCGTTGGCTACCCGTGATATTGCTGAAGAGCTTGGCGGCGAATGGGCTGAC CGCTTCCTC

greenhouse, field plots, and greenhouse raised beds, and treated them with stoichiometric macro-mineral nutrient solutions; and obtained consistent good results on the RNA enzyme activity of GDH-synthesized RNA since 1998 [2].

\subsection{Functional Structure of the GDH-Synthesized RNA}

Possibility that the repeated plus/plus and plus/minus sequence matches among the GDH-synthesized oligonucleotide RNAs (Table 2) could resemble nucleic acid genetic codes encouraged a discussion on the functional relationship between genetic codes and the repeats in the GDH-synthesized RNA. The cDNAs of GDH-synthesized RNA were inserted into plasmids and sequenced (Table 3 ). The cDNA insert of plasmid 1 (Figure 1) shared one plus/minus sequence match with the mRNA encoding oxalate oxidase of peanut (Table 2). The cDNA insert of plasmid 2 shared one plus/plus sequence match with the mRNA encoding arachin h5 (profilin). The cDNA insert of plasmid 3 shared one plus/plus 
sequence match with the mRNA encoding ubiquitin-conjugating enzyme. The cDNA insert of plasmid 4 shared one plus/minus sequence match with the mRNA encoding peanut type 2 metallothionein. The cDNA insert of plasmid 5 shared one plus/minus sequence match with the mRNA encoding peanut cultivar Yueyou 7 ABA 8'-hydroxylase [48]. The cDNA insert of plasmid 7 shared one plus/plus sequence match with the mRNA encoding peanut cultivar fuhua 8 glutamate dehydrogenase 1 . The cDNA insert of plasmid 9 shared one plus/minus sequence match with the mRNA encoding peanut strain E2-4-83-12 delta-12 fatty acid desaturase. The cDNA insert of plasmid 10 shared a plus/plus sequence match with the mRNA encoding peanut cultivar fuhua 8 glutamate dehydrogenase 1 , the second copy of that silencing RNA synthesized by GDH. The cDNA insert of plasmid 11 shared a plus/plus sequence match with the mRNA encoding peanut cultivar JL24 phenylalanine ammonia-lyase. The cDNA insert of plasmid 13 shared three sequence matches, two of which were plus/plus with $+2 /+1$ frame shifts, and one was minus/minus with $-2 /-3$ frame shifts to the mRNA encoding peanut beta-ketoacyl-ACP synthase 11 . This is a complex three-point binding by the GDH-synthesized RNA for wider sequence coverage and total silencing of the mRNA encoding ketoacyl-ACP synthase. Therefore, each insert cDNA of GDH-synthesized RNA (nongenetic code-based RNA) is a unit sequence code for a specific mRNA (genetic code-based RNA).

The DNA insert of plasmid 14 shared sequence match with a section of gnl|uv|U37573.1 phagemid vector pBK-CMV, a component of TOPO TA cloning vector.

The cDNA insert of plasmid 15 shared a plus/plus sequence match with peanut Ara h5 mRNA, being the second copy of that RNA synthesized by GDH. These are evidence that the synthesis of RNA by GDH is reproducible although it is template-independent. The cDNA insert of plasmid 16 shared two plus/minus sequence matches with the mRNA encoding peanut mitogen-activated protein kinase 2 (DQ068453.1); and with the mRNA encoding peanut mitogen-activated protein kinase 3 (EU182580.2). Therefore, the same fragment of RNA synthesized by GDH shared homology with two different mRNAs. This is another example of the complex mechanism, may be involving silencing RNA mass action effect (organic chemical reaction) on mRNA silencing by GDH-synthesized RNA. The cDNA insert of plasmid 17 shared minus/minus sequence match with -1/-3 frame shift to the mRNA encoding Arachis hypogaeae thylene-responsive element binding factor 1 [49]. The cDNA insert of plasmid 18 shared plus/plus sequence match with the mRNA encoding Arachis hypogaea triacylglycerol lipase 1. The cDNA insert of plasmid 19 shared three plus/plus sequence matches with the mRNA encoding peanut mitogen-activated protein kinase 3 (EU182580.2); with the mRNA encoding peanut mitogen-activated protein kinase 2 (DQ068453.1); and with the mRNA encoding peanut mitogen activated protein kinase 1 (DQ068452.1). Plasmid 19 is different from plasmid 16. Therefore, GDH synthesized two different silencing RNA fragments that targeted different sites in the mRNAs encoding the mitogen-activated protein kinases. This 
is another example of the complex mechanism involving reiterated RNA enzyme mass action effect on mRNA silencing. The cDNA insert of plasmid 20 shared two plus/plus sequence matches with the mRNA encoding arachin Ary-3.

The DNA insert of plasmid 21 shared sequence match with a section of gnl|uv|J01636.1 E. coli lactose operon lacI, lacZ, lacY and lacA genes, a component of PCR 4 TOPO TA cloning vector. The DNA insert of plasmid 22 shared sequence match with a section of gnl|uv|J01749.1 of pBR322, a component of PCR 4 TOPO TA cloning vector. The DNA insert of plasmid 23 shared sequence match with a section of gnl|uv|U37573.1 phagemid pBK-CMV. The DNA insert of plasmid24 shared sequence match with a section of gnl|uv|X65311.2 vector pGEM-7Zf(-), component of TOPO TA cloning vector. The DNA insert of plasmid25 shared sequence match with a section of gnl|uv|X65310.2 vector pGEM-7Zf(+), component of TOPO TA cloning vector. The DNA insert of plasmid 27 shared sequence match with a section of gnl|uv|NGB00350.1 Invitrogen pZErO-2 vector multiple cloning site, component of TOPO TA vector. The DNA insert of plasmid 29 shared sequence match with a section of gnl|uv|U37573.1 phagemid vector pBK-CMV, a component of TOPO TA cloning vector. Cloning vector DNA inserts 14, 23, and 29 are different lengths from the same $\mathrm{pBK}-\mathrm{CMV}$ section of TOPO TA vector.

Therefore, the GDH-synthesized RNA oligonucleotide units (Table 3) represent the biological codes for recognition of specific mRNA targets in total RNA, the RNA enzyme activity (Figure 2) being the biochemical mechanism for eliminating the undesired mRNAs.

\subsection{Biotechnological Applications of GDH-Synthesized RNA}

In vitro demonstration of the RNA enzyme activity of GDH-synthesized RNA reveals a smart approach to save time, space and effort on basic research experimentations with plants because preliminary surveys of the responses of plant metabolism to the environment could be conducted at reduced scales in growth chambers, greenhouse, and field plots specifically to collect sufficient tissues for total RNA and GDH purifications; the phenotypic responses of the plant to mineral nutrients, biochemical regulators, agro-chemicals and other xenobiotics being conducted and interpreted in biochemical cross-over reactions as in Figure 2. The more severe the degradation of total RNA is, the more suppressed will the biochemical pathways be, and accordingly the more pronounced the phenotypic characteristics of the plant would be. The GDH-synthesized RNA enzyme could be labeled to differentiate its identity from total RNA moieties in the cross-over reactions in Figure 2.

Dismantling of the structural constraints imposed on RNA by genetic code liberated RNA to become an enzyme with specificity to degrade unwanted transcripts not on base-pairing as in double stranded siRNA, but on the basis of homologous sequence alignment recognition (Figure 2). This nascent biochemical knowledge describing the natural RNA enzyme activity of the ubiquitous GDH synthesized RNA is perhaps of utmost importance in basic enzymology and mo- 
lecular biology research because the activity readily liquefies homologous transcripts, not complementary transcripts. The discovery of the RNA silencing and splicing processes [10] [43] [50] [51] unleashed a new biology that spontaneously elevated the realms of human ingenuous imagination in the R \& D sciences of medicine and agriculture. Over the past decade, the genetic code-based siRNA mechanism has delayed some of the anticipated technological breakthroughs. Biochemical experimentations with plants [1]-[9] [25] [26] [29] [45] [46] however continued to intuitively suggest the existence of an extensive and generalized metabolic network control system at the RNA level but of a somewhat distinct chemical apparatus from the genetic code-based siRNA system [10] [43] [50] [51]. The RNA logic of the generalized chemical silencing apparatus is more vividly illustrated (Figure 2). Therefore, the nongenetic code-based RNA enzyme may provide wider molecular approaches for controlling the population of undesired transcripts in plant systems.

GDH also synthesizes unit oligonucleotides that silence its own encoded mRNAs (Table 3), a perfect feedback strategy for controlling and for automatically shutting off the RNA enzyme concentration when the environmental conditions are conducive for the rapid growth of the plant. Control of the abundance of transcript populations in plant cells could henceforth be accomplished simply and specifically by applying stoichiometric mixes of mineral nutrient, other agrichemical, N-carboxymethyl chitosan, or biochemical regulator solutions to the plant without the need to re-construct any genes. This is a considerable simplification of scientific research thought in a majority of plant enzymology and molecular biology investigations.

The cDNAs of GDH-synthesized RNA are the Northern blot tools for unraveling the molecular mechanisms underlying the multitude of metabolic networks and biochemical regulations in the cell. Since the GDH-synthesized RNA matches transcript sequences in repeated plus/plus, minus/minus, and/or plus/minus homologous orientations [4] [7] [8] [9] the binding of cDNA strands as labeled probes to transcripts is fail-proof because both strands could potentially bind to the same transcript in Northern hybridization thereby enhancing efficiency of detection of Northern bands. Synthesis of RNA enzyme by GDH is therefore an alternative biotechnology to algorithm design [52] [53] of siRNA and Northern probes. GDH synthesized RNA is however for experimentation on the coordination of biochemical pathways and of metabolic networks. There are yet no algorithm-designed hybridization probe and siRNA for the study of integration/discrimination regulation of biochemical pathways. The frame shifts in the structure of GDH-synthesized RNAs enlarges the span of mRNA/RNA enzyme interaction for improvement of mRNA destruction.

In the application of algorithm-designed siRNAs for the silencing of transcripts, it has been reported that siRNA efficacy is limited by target transcript abundance and turnover rate [54] [55]. The biological phenomenon of transcript turnover rate is further exacerbated by the transcriptome profiling of total tran- 
script extracts from experimental organisms in comparison with an untreated organism as control. Such an untreated control is in its right an experimental treatment, but with unknown chemical environmental conditions. There should be a second control organism with known chemical environmental condition housing the specific control target transcripts. In the induction of GDH synthesized RNA enzyme experimentation, in addition to the control crop, there is a second control crop housing the control GDH [7] [26]. Whereas the control crop's transcripts display many of the turnover rates and abundance observed for the experimental organisms, the transcripts of the control crop that is housing the control GDH are less abundant, displaying a diminished turnover rate pattern that is visibly different from those of the experimental organisms, thereby making for unequivocal and an accurate interpretation of Northern blot and transcriptome results from siRNA profiling experimentations [8] [9]. These considerations emphasize the importance for the inclusion of GDH-synthesized RNA enzyme assays as necessary controls in plant systems molecular biology research projects.

\section{Funding and Acknowledgements}

This research project was supported by the Evans Allen fund made available to Prairie View A \& M University, Prairie View, Texas by USDA NIFA. Appreciation to Drs. Peter Ampim, and Aruna Weerasooriya for discussions on the stoichiometric compositions of the mineral salt mixes.

\section{Conflicts of Interest}

The authors declare no financial competing interests.

\section{References}

[1] Osuji, G.O., Brown, T.K. and South, S.M. (2008) Discovery of the RNA Synthetic Activity of Glutamate Dehydrogenase and Its Application in Drug Metabolism Research. The Open Drug Metabolism Journal, 2, 1-13. https://doi.org/10.2174/1874073100802010001

[2] Osuji, G.O. and Braithwaite, C. (1999) Signaling by Glutamate Dehydrogenase in Response to Pesticide Treatment and Nitrogen Fertilization of Peanut (Arachis hypogaea L.). Journal of Agricultural and Food Chemistry, 47, 3332-3344. https://doi.org/10.1021/jf9805303

[3] Osuji, G.O., Brown, T.K., South, S.M., Duncan, J.C., Johnson. D. and Hyllam, S. (2012) Molecular Adaptation of Peanut Metabolic Pathways to Wide Variations of Mineral Ion Composition and Concentration. American Journal of Plant Sciences, 3, 33-50. https://doi.org/10.4236/ajps.2012.31003

[4] Osuji, G.O., Brown, T.K., South, S.M., Duncan, J.C. and Johnson, D. (2011) Doubling of Crop Yield through Permutation of Metabolic Pathways. Advances in Bioscience and Biotechnology, 2, 364-379. https://doi.org/10.4236/abb.2011.25054

[5] Osuji, G.O., Madu, W.C., Braithwaite, C., Beyene, A., Roberts, P.S., Bulgin, A. and Wright, V. (2003/4) Nucleotide-Dependent Isomerization of Glutamate Dehydrogenase in Relation to Total RNA Contents of Peanut. Biologia Plantarum, 47, 
195-202. https://doi.org/10.1023/B:BIOP.0000022251.40891.ae

[6] Osuji, G.O., Brown, T.K., South, S.M., Duncan, J.C., Johnson, D. and Hyllam, S. (2012) Molecular Modeling of Metabolism for Allergen-Free Low Linoleic Acid Peanuts. Applied Biochemistry and Biotechnology, 168, 805-823. https://doi.org/10.1007/s12010-012-9821-6

[7] Osuji, G.O., Duffus, E., Johnson, P., Woldesenbet, S., Weerasooriya, A., Ampim, P.A.Y., Carson, L., Jung, Y., South, S., Idan, E., Johnson, D., Clarke, D., Lawton, B. and Parks, A. (2015) Enhancement of the Essential Amino Acid Composition of Food Crop Proteins through Biotechnology. American Journal of Plant Sciences, 6, 3091-3108. https://doi.org/10.4236/ajps.2015.619302

[8] Osuji, G.O., Johnson, P., Duffus, E., Woldesenbet, S. and Kirven, J.M. (2017) Horticultural Production of Ultra-High Resveratrol Peanut. Agricultural Sciences, 8, Article ID: 80053.

[9] Osuji, G.O., Gao, M., Carson, L., Ampim, P., Weerasooriya, A., Johnson, P., Duffus, E., Woldesenbet, S., Kirven, W.E., Johnson, D. and Clarke, D. (2017) Biotechnological Production of Shikimate-Based Antioxidant Accumulation in Phyla dulcis. The Natural Products Journal, 7, 104-111. https://doi.org/10.2174/2210315506666161017124440

[10] Cech, T.R. (1986) RNA as an Enzyme. Scientific American, 255, 64-75. https://doi.org/10.1038/scientificamerican1186-64

[11] Klahre, U., Crete, P., Leuenberger, S.A., Iglesias, V.A. and Meins, F. (2002) High Molecular Weight RNAs and Small Interfering RNAs Induce Systemic Postrranscriptional Gene Silencing in Plants. Proceedings of the National Academy of Sciences of USA, 10, 1073-1078.

[12] Agrawal, N., Dasaradhi, P.V.N., Mohamed, A., Malhotra, P., Bhtnagar, R.K. and Mukherjea, S.K. (2003) RNA Interference: Biology, Mechanism, and Applications. Microbiology and Molecular Biology Reviews, 67, 657-685. https://doi.org/10.1128/MMBR.67.4.657-685.2003

[13] Di Chiacchio, L., Sloma, M.F. and Mathews, D.H. (2016) Access Fold: Predicting RNA-RNA Interactions with Consideration for Competing Self-Structure. Bioinformatics, 32, 1033-1039. https://doi.org/10.1093/bioinformatics/btv682

[14] Meyer, I.M. (2008) Predicting RNA-RNA Interactions. Current Opinion in Structural Biology, 18, 387-393. https://doi.org/10.1016/j.sbi.2008.03.006

[15] Clowney, L., Jain, C.S., Srinivasan, A.R., Westbrook, J., Olson, W.K. and Berman, H.M. (1996) Geometric Parameters in Nucleic Acids. Nitrogenous Bases. Journal of American Chemical Society, 118, 509-518. https://doi.org/10.1021/ja952883d

[16] Chan, C.Y., Carmack, C.S., Long, D.D., Maliyekkel, A, Shao, Y., Roninson, I.B. and Ding, Y. (2009) A Structural Interpretation of the Effect of GC-Content on Efficiency of RNA Interference. BMC Bioinformatics, 10, S33. https://doi.org/10.1186/1471-2105-10-S1-S33

[17] Mann, S. and Chen, Y.P. (2010) Bacterial Genomic G+C Composition-Eliciting Environmental Adaptation. Genomics, 95, 7-15. https://doi.org/10.1016/j.ygeno.2009.09.002

[18] Smarda, P., Bures, P., Horova, L., Leitch, I.J., Mucina, L., Tichy, G.V. and Rotreklova, O. (2014) Ecological and Evolutionary Significance of Genomic GC Content Diversity in Monocots. Proceedings of the National Academy of Sciences, 111, E4096-E4102. https://doi.org/10.1073/pnas.1321152111

[19] Liu, L., Li, Q., Lin, H. and Zou, Y. (2013) The Effect of Regions Flanking Target Site 
on siRNA Potency. Genomics, 102, 215-222.

https://doi.org/10.1016/j.ygeno.2013.07.009

[20] Oliver, J.L. and Marin, A. (1996) A Relationship between GC Content and Coding-Sequence Length. Journal of Molecular Evolution, 43, 216-223.

https://doi.org/10.1007/BF02338829

[21] Yakovchuk, P., Protozanova, E. and Frank-Kamenetskii, M.D. (2006) Base-Stacking and Base-Pairing Contributions into Thermal Stability of the DNA Double Helix. Nucleic Acids Research, 34, 564-574. https://doi.org/10.1093/nar/gkj454

[22] Krutinin, G.G., Krutinina, E.A., Kamzolova, S.G. and Osypov, A.A. (2015) Bacteriophage $\lambda$ : Electrostatic Properties of the Genome and Its Elements. Molecular Biology, 49, 339-347. https://doi.org/10.1134/S0026893315030115

[23] Cuervo, A., Dans, P.D., Carrascosa, J.L., Orozco, M., Gomila, G. and Fumagalli, L. (2014) Direct Measurement of the Dielectric Polarization Properties of DNA. Proceedings of the National Academy of Sciences, 111, E3624-E3630. https://doi.org/10.1073/pnas.1405702111

[24] Vologodskii, A. and Cozzarelli, N. (1995) Modelling Long-Range Electrostatic Interactions in DNA. Biopolymers, 35, 289-296. https://doi.org/10.1002/bip.360350304

[25] Osuji, G. and Brown, T. (2007) Role of the RNA Synthesized by Glutamate Dehydrogenase in the Coordinate Regulation of Metabolic Processes. The ICFAI Journal of Biotechnology, 1, 37-48.

[26] Osuji, G.O. and Madu, W.C. (2015) Glutamate Dehydrogenase. In: D’Mello, J.P.F., Ed., Amino Acids in Higher Plants, CABI Publishers, Oxfordshire and Boston, 1-29. https://doi.org/10.1079/9781780642635.0001

[27] Grierson, D., Slater, J. and Tucker, G.A. (1985) The Appearance of Polygalacturonase mRNA in Tomatoes. Planta, 163, 263-271. https://doi.org/10.1007/BF00393517

[28] Loyola-Vargas, V.M. and De Jimenez, E.S. (1984) Differential Role of Glutamate Dehydrogenase in Nitrogen Metabolism of Maize Tissue. Plant Physiology, 76, 536-540. https://doi.org/10.1104/pp.76.2.536

[29] Osuji, G.O., Konan, J. and M'Mbijjewe, G. (2004) RNA Synthetic Activity of Glutamate Dehydrogenase. Applied Biochemistry and Biotechnology, 119, 209-228. https://doi.org/10.1007/s12010-004-0003-Z

[30] Altschul, S.F., Gish, W., Miller, W., Myers, E.W. and Lipman, D.J. (1990) Basic Local Alignment Search Tool. Journal of Molecular Biology, 215, 403-410. https://doi.org/10.1016/S0022-2836(05)80360-2

[31] Tatusova, T. and Madden, T.L. (1999) Blast 2 Sequences-A New Tool for Comparing Protein and Nucleotide Sequences. FEMS Microbiology Letters, 174, 247-250. https://doi.org/10.1111/j.1574-6968.1999.tb13575.x

[32] Don, R.H., Cox, P.T., Wainwright, B.J., Baker, K. and Mattick, J.S. (1991) “Touchdown" PCR to Circumvent Spurious Priming during Gene Amplification. Nucleic Acids Research, 19, 4008. https://doi.org/10.1093/nar/19.14.4008

[33] Erlich, H.A., Gelfand, D. and Sninsky, J.J. (1991) Recent Advances in the Polymerase Chain Reaction. Science, 252, 1643-1651. https://doi.org/10.1126/science.2047872

[34] Kramer, M.F. and Coen, D.M. (2001) Enzymatic Amplification of DNA by PCR: Standard Procedures and Optimization. Current Protocols in Toxicology, 3, 1-14.

[35] Korbie, D.J. and Mattick, J.S. (2008) Touchdown PCR for Increased Specificity and Sensitivity in PCR Amplification. Nature Protocols, 3, 1452-1456.

https://doi.org/10.1038/nprot.2008.133 
[36] Glemin, S., Clement, Y., David, J. and Ressayre, A. (2014) GC Content Evolution in Coding Regions of Angiosperm Genomes: A Unifying Hypothesis. Trends in Genomes, 30, 263-270. https://doi.org/10.1016/j.tig.2014.05.002

[37] Vinogradov, A.E. (2003) DNA Helix: The Importance of Being GC-Rich. Nucleic Acids Research, 31, 1838-1844. https://doi.org/10.1093/nar/gkg296

[38] Meier-Kolthoff, J.P., Klenk, H. and Goker, M. (2014) Taxonomic Use of DNA G+C Content and DNA-DNA Hybridization in the Genomic Age. International Journal of Systematic Environmental Microbiology, 64, 352-356.

[39] Bernadi, G. (1989) The Isochore Organization of the Human Genome. Annual Review of Genetics, 23, 637-661.

[40] Frank-Kamenetskii, M.D. (1987) How the Double Helix Breaths. Nature, 328, 17-18. https://doi.org/10.1038/328017a0

[41] Krueger, U., Bergauer, T., Kaufmann, B., Wolter, I., Pilk, S, Heider-Fabian, M., Kirch, S., Artz-Oppitz, C., Isselhorst, M. and Konrad, J. (2007) Insights into Effective RNAi Gained from Large-Scale siRNA Validation Screening. Oligonucleotides, 17, 237-250. https://doi.org/10.1089/oli.2006.0065

[42] Stein, C.A. (1998) How to Design an Antisense Oligodeoxynucleotide Experiment: A Consensus Approach. Antisense and Nucleic Acid Drug Development, 8, 129-132. https://doi.org/10.1089/oli.1.1998.8.129

[43] Cech, T.R., Zaug, A.J. and Grabowski, P.J. (1981) In Vitro Splicing of the rRNA Precursor of Tetrahymena: Involvement of a Guanosine Nucleotide in the Excision of the Intervening Sequence. Cell, 27, 487-496. https://doi.org/10.1016/0092-8674(81)90390-1

[44] Eckstein, F. and Lilley, D.M.J. (1996) Catalytic RNA. In: Nucleic Acids and Molecular Biology, Vol. 10, Springer-Verlag, Berlin.

[45] Osuji, G.O., Brown, T.K. and South, S.M. (2010) Optimized Fat and Cellulosic Biomass Accumulation in Peanut through Biotechnology. International Journal Biotechnology and Biochemistry, 6, 445-476.

[46] Osuji, G.O., Weerasooriya, A., Ampim, P.A.Y., Carson, L., Johnson, P., Jung, Y., Duffus, E., Woldesenbet, S., South, S., Idan, E., Johnson, D., Clarke, D., Lawton, B., Parks, A. and Fares, A. (2015) Molecular Regulation of the Metabolic Pathways of the Medicinal Plants: Phyla dulcis. American Journal of Plant Sciences, 6, 1717-1726. https://doi.org/10.4236/ajps.2015.611171

[47] Takahashi, S., Yeo, Y., Greenhagen, B.T., McMullin, T., Song, L., Maurina-Brunker, J., Rosson, R., Noel, J.P. and Chappell, J. (2007) Metabolic Engineering of Sesquiterpene Metabolism in Yeast. Biotechnology and Bioengineering, 97, 170-181. https://doi.org/10.1002/bit.21216

[48] Liu, S., Lv, Y., Wang, X.R., Li, L.M., Hu, B. and Li, L. (2014) Cloning and Expression Analysis of cDNAs Encoding ABA 8'-Hydrolase in Peanut Plants in Response to Osmotic Stress. PLoS ONE, 9, e97025. https://doi.org/10.1371/journal.pone.0097025

[49] Chen, N., Yang, Q., Su, M., Pan, L., Chi, X., Chen, M., He, Y., Yang, Z., Wang, T. and Yu, S. (2012) Cloning of Six EFR Family Transcription Factors Genes from Peanut and Analysis of Their Expression during Abiotic Stress. Plant Molecular Biology Reporter, 30, 1415-1425. https://doi.org/10.1007/s11105-012-0456-0

[50] Strobel, S.A. and Cochrane, J.C. (2007) RNA Catalysis: Ribozymes, Ribosomes and Riboswitches. Current Opinion in Chemical Biology, 11, 636-643.

[51] Lilley, D.M.J. (2011) Mechanisms of RNA Catalysis. Philosophical Transactions of 
the Royal Society B: Biological Sciences, 366, 2910-2917. https://doi.org/10.1098/rstb.2011.0132

[52] Miyagishi, M. and Taira, K. (2005) siRNA Becomes Smart and Intelligent. Nature Biotechnology, 23, 946-947. https://doi.org/10.1261/rna.7275905

[53] Jagla, B., Aulner, N., Kelly, P.D., Song, D., Volchuk, A., Zatorski, A., Shum, D., Mayer, T., De Anglis, D.A., Ourfelli, O., Rutishauser, U. and Rothman, J.E. (2005) Sequence Characteristics of Functional siRNAs. RNA, 11, 864-872.

[54] Larsson, E., Sander, C. and Marks, D. (2010) mRNA Turnover Rate Limits siRNA and microRNA Efficacy. Molecular Systems Biology, 6, 433.

https://doi.org/10.1038/msb.2010.89

[55] Hong, S.W., Jang, Y., Kim, S., Li, C.J. and Lee, D. (2014) Target Gene Abundance Contributes to the Efficiency of siRNA-Mediated Gene Silencing. Nucleic Acid Therapeutics, 24, 192-198. https://doi.org/10.1089/nat.2013.0466 